\title{
Social Development Strategies for Promotion of Community Development in Nigeria
}

\author{
Dr. (Mrs) A.N. Ugwu Dr. E. O. Aruma \\ Department of Adult And Non-Formal Education, University of Port Harcourt, Port Harcourt, Pmb 5323, Port \\ Harcourt, Rivers State, Nigeria
}

\begin{abstract}
Every social action is perceived as a joint undertaking of' people in their social settings to improve their living conditions in various communities in the society. Social development as an educational process stimulates consciousness among people in order to be aware of their capabilities to address prevailing situations and realities in various participating communities. Social development as a concept is used to stimulate awareness in people for the ultimate purpose of understanding their social realities ant their potentialities to promote development that will improve their living conditions in their various communities. The paper identified conscientisation strategy, communication strategy and group action strategy as strategies of social development in stimulating community development. Based on the issues discussed appropriate recommendations are made which include the urgent need to ensure that adequate information is made available to people through the instrumentality of conscientisation and communication as well as that social development should be driven by common vision and interest of the people of participating communities in Nigeria.
\end{abstract}

Keywords: Social Development, Strategies, Promotion, Community Development

DOI: $10.7176 / \mathrm{JEP} / 11-11-07$

Publication date: April $30^{\text {th }} 2020$

\section{Introduction}

The concept of social development can be viewed as an educational process which stimulates consciousness among people in order to be aware of their capabilities to address prevailing situations or realities in participating communities in the society. Pratt and Boyden (1985) use the term social development to refer to projects which try to develop self-reliance among people and encourage their active participation and awareness creation of their social reality and ability to influence and direct their own lives in the society. Essentially, social development is a concept which is used to stimulate awareness creation in people to understand their social reality and their capability to promote change or development that will improve their living conditions in the participating communities in the society. Social development as a development concept encourages active participation of people in development initiatives that will ultimately improve their poor living conditions.

Community development is defined as a process which elicits the collaborative efforts of members of various communities being united with governmental authorities and other relevant stakeholders in order to improve people's living conditions in the concerned communities in the society. Aruma (2015) defines community development as the process whereby the efforts of the members of participating communities are united with those of governmental authorities, non-governmental organizations (NGOs), corporate organizations, wealthy individuals and other relevant stakeholders for the ultimate purpose of improving people's living conditions in the participating communities. UNESCO (1975:5) views community development as:

The process by which the efforts of the people themselves are united

with those of governmental authorities to improve the economic, social and cultural conditions of communities, to integrate those communities into the life of the nation and to enable them to contribute fully to national progress.

In the view of Nwangwu in Ugwu (2013), community development is a conscious effort by members of a community (indigenes) or agencies interested in the community (outsider) to chart a course that will move the community in question forward to a better and more desirable future.

However, anyway community development is approached, Frank and Smith in Ugwu and Aruma (2019) affirmed that it is a process that will eventually make community members responsible for their own development, strengthen their capacity, empower them, reduce ignorance and poverty and help them achieve social, economic, cultural and environmental goals.

Interestingly, community development as a process has assumed collaborative engagement dimension in the contemporary global environment whereby the efforts of members of various participating communities are united with those of governmental authorities and other relevant stakeholders to address development challenges in order to improve people's living conditions at community level in the society. The intervention of social development in stimulating awareness creation among all the relevant stakeholders in community development initiative will certainly enable them to understand the potentialities of unified efforts to achieve a common vision and interest of 
improving people's living conditions in the participating communities in the society.

\section{The Strategies of Social Development for Promotion of Community Development in Nigeria}

The strategies of social development for stimulating community development in various communities are as follows:

1. Conscientistation strategy

2. Communication strategy

3. Group action strategy

\section{Conscientisation Strategy}

The concept of conscientisation can be defined as social awareness or awareness creation which empowers people to acquire relevant knowledge in order to understand the problems that confront them and proffer solutions to the identified problems in their various localities in the society. Conscientisation brings emerging ideas and knowledge to people in order to help them have an understanding of the prevailing realities of their situation. The concept of conscientisation as advocated by Freire (1985) is viewed as a process which helps people to develop themselves, their consciousness and critical thinking, or awareness of their own problems and environment or situation with a view to addressing them appropriately. Nzeneri (2010) perceives the concept of conscientisation as awareness education. As an awareness educations concientisation has transformational power to transform people who are privileged to receive it.

Conscientisation as a strategy of adult education and social development focuses on empowering people with ideas and knowledge for liberation from numerous problems in the society. Freire (1985) states that conscientisation is based on new idea of education as education for liberation and not on the old idea of education as education for domination or domestication which views education as a way of transferring knowledge from the teacher as the reservoir of knowledge to the learner or student as the tabula rasa or empty mind of the learner or student. In understanding the transformative elements of education. Nzeneri (2010) perceives education for liberation as a dynamic process which sees knowledge as transforming people and societies rather than transferring knowledge in the society. This brings to focus the transformation agenda of the government of Federal Republic of Nigeria under the leadership of former President Goodluck Ebele Jonathan, who made transformation agenda a cardinal policy of his administration. Consequently. conscientisation has the power to transform people and various participating communities when it is applied appropriately in educational process in the society. Freire (1985) asserts that the use of active, generative, creative and transformative words should be applied appropriately instead of idle, weak, empty and meaningless words. The idea for this is to motivate people into meaningful collective action that will ultimately lead to improved living conditions in various participating communities in the society.

Conscientisation as a social development process focuses on stimulating appropriate transformative action to address prevailing realities in human environment. Akande (2016) states that conscientisation as a social process shapes the lives of people and helps them to take action to transform the realities in their local environment. Conscientisation as a strategy of social development for promotion of community development stimulates consciousness in people to mobilize themselves and their scarce resources to address prevailing issues of common concern in human environment. Akande (2016) asserts that conscientisation as a social process takes place among people as they unite in common reflection and action upon their prevailing situation. The implication of this is that conscientisation stimulates reflective thinking and appropriate action of people of various communities to address prevailing issues of common concern in human environment.

The intervention of social awareness building is very critical to stimulate people's awareness or consciousness to have good understanding of the numerous problems that confront them in their various localities in human environment. Feuerstein (1988) identifies social awareness building for people at local community level to conscientise them. Aruma (2012) rightly states that conscientisation affords people an opportunity to know very well about the problems in their local social settings in human environment. Conscientisation as a strategy of social development for promotion of community development helps people to understand the prevailing realities of their local environment.

Essentially, conscientisation is very fundamental to adult education and social development process of helping people to acquire relevant information and knowledge that will certainly lead to their enhanced living conditions. Mulwa (2008) states that conscientisation programmes are fundamental to the whole process of empowerment of the people in the society. He identifies four main elements in this regard which are the followings:

1. The process of conscientisation takes place in a group.

2. The transforming process of conscientisation is on-going.

3. Conscientisation helps people to understand their own prevailing realities or problems in the society.

4. The ultimate objective of conscientisation is to change unjust economic, social and decision-making processes and structures that are the causes of the problems confronting people in their localities in the society. 
1. Conscientisation is Group Action-Oriented: Conscientisation as group action- oriented is an important element of conscicntisation in social development for promotion of community development. The process of conacientisation takes place in a group in human environment. Mulwa (2008) notes that communal raising of awareness empowers people to embark on community action. While commenting on a similar subject, Akande (2016) views community development from Freirean conscientisation perspective as a cultural action for freedom where people of various communities are encouraged to think very well about their common problems and actions to address them accordingly. Indeed, conscientisation of people at community level stimulates community-oriented action in addressing prevailing community challenges in the participating communities.

2. Transformation Power of Conscientisation as an Ongoing Process: The transformation power of conscientisation as an on-going process is another important element of conscientisation in adult education and social development for promotion of community development. Mulwa (2008) states that the transforming process of conscientisation is on-going and ever deepening in the society. Conscientisation of people that stimulates awareness creation among them calls for reflective thinking leading to group action or collective action to transform prevailing reality or situation in the participating communities in the society.

3. Conscientisation Stimulates Understanding of People's Prevailing Realities or Problems: Another element of conscientisation in social development for promotion of community development is that it stimulates understanding of people's prevailing realities or problems. Mulwa (2008) acknowledges that conscientisation helps people to really understand their own reality in the society. Conscientisation, indeed, enables people to really understand their prevailing situations and their potentialities to address them in the society.

4. The Power or Ability of Conscientisátion to Change Prevailing Situation: The power or ability of conscientisation to change prevailing situation is equally another element of conscientisation in social development 'for promotion of community development. Ultimately, concientisation stimulates positive change in order to address the prevailing situation. Mulwa (2008) observes that the ultimate objective of conscientisation is to change unjust economic, social and decision-making process and structures that are the causes o the problems confronting people in their localities in the society. This demands that people should have a good understanding of their problems in human environment. Freire (1985) states that people's desire to deepen awareness creation of the prevailing socio-cultural realities repositions their lives through taking appropriate actions to transform the realities in the society. The ability of conscientisation to change prevailing situations depends to a certain extent on stimulating an understanding among the concerned people to engage in reflective thinking and subsequently initiating appropriate group action to address their issues of common concern in human environment.

5. The Ability of Conscientisation to Sustain the Emerging people-Oriented Changes: The ability of conscientisation to sustain the emerging people-oriented changes that improve the living conditions of people is another important element of conscientisation in adult education and social development for promotion of community development initiative. People critically evaluate their social situation in order to be able to put in place alternative mechanism for more efficient management of their community development projects that will address their problems appropriately in their localities. Reflecting on prevailing reality or problem, conscientisation builds and strengthens the economic base of the people in the society. Mulwa (2008) states that consccn1 sation which does not improve economic base of the people will end in frustration in the society. Awareness creation must lead to an improvement in management of community development projects in order to guarantee their sustainability for improved living conditions of people.

\section{Communication Strategy}

Communication strategy is also a very important strategy of social development for promotion of community development in Nigeria. The concept of communication is defined as a process by which people exchange information or express their thoughts, concerns and feelings in the society. Essentially, communication is the live wire of human society.

Fundamentally, communication is critical for human existence since it enhances human interaction in the society. The cornerstone of social development as it concerns adult education and community development is communication, It is obvious that no development initiative can take place without communication in the society. In the process of communication, ideas are generated and released by a person known as the originator of the information or sender of the information or encoder and received by another person as receiver or decoder who decodes or interprets the information based on his/her understanding of the message. Communication is as old as human race. It is based on communication that the work of creation of the first man-Adam by God became a reality. It should be noted that in the account of creation that God said "let us make man in our own image" (Gen. 1:26- 
27). There is no human interaction without communication in the society.

The concept of communication is simply defined as the process of passing on ideas, information or message from one person to another person or persons in order to enhance understanding for improved human interaction in the society. The concept of communication can also be defined as a process by which people exchange information or express their thoughts, concerns and feelings in order to stimulate understanding of the message being communicated in the society. Udeinya (1987) defines communication as the act of passing on to another person what people feel, wish or think about themselves or somebody or something in the society. The passing on of the information is usually by means of symbols or language that is mutually agreed and understood by the concerned people in the communication process in the society. Mulwa (2008) remarks that people use signals to communicate in the society. It is good to use signals which target audience will understand in the society.

\section{The Functions of Communication in Social Development for Promotion of Community Development}

Communication does the following things in social development for the promotion of community development in the society:

1. Transmits or conveys ideas, information or message

2. Encourages understanding of the ideas, information or message.

3. Stimulates action either individually or group action.

4. Promotes change to improve people's living conditions in the Society:

D'Souza (1995) asserts that communication is intended to bring information and ensure understanding of the message as well as to get action and persuade for change or support in the society, The realization of this, therefore, becomes obvious when the communicator, facilitator or sender of the information or message is able to identify his/her audience or receiver appropriately. This will enable him/her to share his/her ideas, information or message very well with the identified target audience or receiver in social development process. Pratt and Boyden (1985:156) rightly remark that:

Every social development project involves communication;

communication among members of a community or group;

communication between development workers and the people among

whom they work; communication between funding agencies and field

workers, and so on. Communication involves the sharing of ideas- of

information, of emotions, of hopes and fears-and is part of every

human activity.

Consequently, communication in social development provides the following functions to people in the society:

1. Provision of information

2. Promotion of discussion and dialogue

3. Sharing of experience

4. Sharing of ideas

5. Awareness creation

6. Stimulating interest

7. Promoting attitudinal change among others.

\section{Group Action Strategy}

Group action strategy is another important strategy for stimulating community concerns for promotion of community development. The concept of group action is defined as social movement of an organized group which mobilizes people for the ultimate purpose of addressing prevailing realities in order to improve the living conditions of people in their communities in the society. Schaefer (2005) defines the concept of group action as new social movement which focuses on collective actions to address values and social identities of people with a view to improving the quality of life of people in the society. Essentially, the focus of group action strategy of social development is to stimulate collective consciousness among people to come together in order to address prevailing problems in their various communities. The reason for this is basically to seek possible ways of addressing problems of common concern in order to improve people's poor living conditions in the society.

Group action strategy is viewed as goal-oriented development initiatives in the contemporary society. Aruma (2015) states that group action strategy places emphasis on goal-driven development initiatives in various communities in the society. He concludes that an action becomes goal-driven when its focus is on achieving the much desired objectives and goals in the society.

The efforts of an individual alone cannot sustain group action in social development initiative in the society. Aruma (2015) asserts that group action strategy is not action-oriented human activity that a person as an individual will be able to sustain alone in the society. He further observes that group action strategy elicits collective responsibilities which enables people to address prevailing problems in participating communities. D'Souza (1995) states that members of a group, indeed, share responsibilities for their effectiveness in service delivery. Social 
development as people-oriented development initiative is based on group action and collective responsibilities of members of the concerned participating communities.

Interestingly, every social action is seen as a joint undertaking for group action in human environment. The social development initiative, therefore, calls for collaborative engagement of members of a social group that is committed to work together for the ultimate purpose of improving people's living conditions through the instrumentality of social development process. The members of a group in social development must certainly have certain things in common which characterize the group in the society. These include common identity, common problems, common interest and goal driven development initiatives (Aruma, 2015). The sense of solidarity and shared collective responsibilities will usually stimulate people into action to work diligently to promote sustainable community development initiatives which will focus on improving people's living conditions in the society.

\section{Conclusion}

There is no human activity without communication in human environment. Communication as an important strategy of social development from the perspectives of adult education and community development is very much critical for human existence since it enhances human interaction in the society. The cornerstone of social development as it concerns adult education and community development is communication.

As an awareness education, conseicatisation has transformational power to transform people who are privileged to receive it. The use of active, generative, creative and transformative words should be applied appropriately instead of idle and weak words in order to stimulate group action in social development for community development in Nigeria.

Social development will reposition the thinking of people in various communities in Nigeria to desire better life for both the present and future generations. The desire for social development will help various participating communities to attain better knowledge, better freedom, better life, better health services, an enhanced food production, food security and improved living conditions. The implication of this is that people will help to improve their own lives by themselves through active participation and collective efforts of all and sundry in the participating communities in the country.

\section{Recommendations}

The following recommendations are made based on the issues discussed on social development strategies for promotion of community development in Nigeria:

1. There is the need to ensure that adequate information is made available to people through the instrumentality of conscientisation and communication as important strategies for social development in promolion of community development in various communities in Nigeria. The information that will be acquired from conseientisation and communication as strategies of social development in promoting community development should aim at transforming people's lives for better in various communities in Nigeria.

2. Social development should be driven by common vision and interest of the people of Nigeria. The common vision and interest should aim at transforming people's lives at personal, family, small group, community, organizational and institutional levels. This social development initiative will lead to transformation of people's lives, communities, institutions, organizations and the society in general.

3. There should be an understanding that social development is very much. desirable for more fulfilling community life, in collaborating with the governmental authorities, non-governmental organizations (NGOs), corporate organizations (COs) and other relevant stakeholders in the country. This can be achieved through the instrumentality of transformative education of social development which focuses on the premise that it is possible to change life for the better through active participation of members of the participating communities in the society.

4. The concern for common good based on common mission, vision and interest elicits for mutual cooperation and social justice in Nigeria. It is obvious that Nigerians desire better life both for the present and future generations in the country.

5. The curriculum social of development should be relevant to people's needs in various communities. This will make the development agenda and education to focus on people-oriented needs in the country.

\section{References}

Akande, J.O. (2016). Understanding community development: A handbook for educators and practitioners. IleIfe: Obafemi Awolowo University Press.

Aruma, E. O. (2015). Strategies of community development in promotion of social change in participating communities in the society. In Journal of Economics and Sustainable Development, 6 (3), 223-227.

Aruma, E.O. (2016). Youth empowerment as a strategy for promoting sustainable development in Nigeria. In Ward, J.L.J.D. (Ed.) The Intuition: An International Journal of Association for Research Development, 2(1), 
$86-92$.

D’Souza A, A. (1995). Leadership. Bombay: Better Yourself Books,

Feuerstein, M.T. (1988). Partners in evaluation: Evaluating community programmes with partners. London: Macmillan publishers Limited.

Freire, P. (1985), Pedagogy of the oppressed. London: Pengium Books.

Ihejirika, J.C. (2012). Anatomy of adult education. Port Harcourt: University of Port Harcourt Press.

Mulwa, F. W. (2008). Demystifying participatory community development. Nairobi: Paulines Publications Africa. Nzeneri, 1. S. (2010). Handbook on adult education principles and practices. New Edition. Uyo: AbiGab Associates Ltd

Pratt, B. and Boyden, J. (1985). The. field directors' handbook: An Oxfam manual for development workers. Oxford: Oxford University Press.

Schaefer, R. T. (2005). Sociology ninth edition. Boston: McGraw Hill.

Udeinya, C. S. (1987). Principles of education communication. In S. Anih (Ed.) Fundamentals, innovations and issues in education. Enugu: Institute of Ecumenical Education. 137-144.

Ugwu, A.N. and Aruma, E.O. (2019). Community participation as a tool for the promotion of community development. International Journal of Community and Cooperative Studies. 7(1), 1-10.

Ugwu, A. N. (2013). Conflict management for sustainable community development in Nigeria in the $21^{\text {st }}$ century. In Eheazu, B.A., Barikor, C.N. and Nzeneri, I.S. (Eds) Readings in adult and non-formal education. Port Harcourt: University of Port Harcourt Press, 1, 199-211.

UNESCO (1975). Final report of the seminar on structure of adult education in developing countries with special reference to Africa. Nairobi: UNESCO. 